\title{
Low skeletal mass is an important predictor of osteoporosis in HIV-infected men in India
}

\author{
Niska masa szkieletu ważnym czynnikiem predykcyjnym osteoporozy \\ u mężczyzn zakażonych wirusem HIV w Indiach
}

\author{
Deep Dutta ${ }^{1,2}$, Meha Sharma ${ }^{3}$, Rahul Bansal ${ }^{2}$, Neera Sharma ${ }^{4}$, Umesh Chandra Garga ${ }^{5}$, Atul Anand $^{6}$, \\ Kumar Gaurav ${ }^{2}$
}

${ }^{1}$ Department of Endocrinology, Diabetology \& Metabolic Disorders, Venkateshwar Hospital, Dwarka, New Delhi, India ${ }^{2}$ Department of Endocrinology, Postgraduate Institute of Medical Education E Research (PGIMER) E Dr. Ram Manohar Lohia (RML) Hospital, New Delhi, India

${ }^{3}$ Department of Rheumatology, Venkateshwar Hospital, Dwarka, New Delhi, India

${ }^{4}$ Department of Biochemistry, PGIMER \& Dr. RML Hospital, New Delhi, India

${ }^{5}$ Department of Radiology, PGIMER \& Dr. RML Hospital, New Delhi, India

${ }^{6}$ Anti-retroviral Therapy Clinic, PGIMER \& Dr. RML Hospital, New Delhi, India

\begin{abstract}
Introduction: This study evaluated prevalence and predictors of osteoporosis and sarcopaenia in men with HIV.

Material and methods: A total of 220 men with HIV were screened, of which 115 men, 30-50 years-age, having at least one-year followup, underwent hormonal and DEXA analysis. Forty controls were also evaluated.

Results: Males with HIV had significantly lower BMD and Z-scores at all sites. Osteoporosis was diagnosed in $64.35 \%$, the commonest site being radius total $(49.56 \%)$, followed by radius $33 \%(45.21 \%)$, radius ultra distal $(36.52 \%)$, lumbar spine (19.13\%), neck of femur $(17.39 \%)$, and total femur and greater trochanter (7.82\% each). HIV patients had significantly lower fat mass (FM), lean mass (LM), total fat percentage, bone mineral content, gynoid fat, and percentage skeletal muscle mass (PSMM). Men with osteoporosis had higher use of anti-retroviral therapy (ART), immune reconstitution inflammatory syndrome (IRIS), tuberculosis, and lower FM, LM, and PSMM. Logistic regression revealed that PSMM, age, and delta $(\Delta)$ CD4 count (change in CD4 count after 6-12 months of ART, compared to pre-ART) were the best predictors of osteoporosis. Greater PSMM was associated with decreased osteoporosis, without adjusting for any variable (Model-1), adjusting for disease duration, tuberculosis and IRIS (Model-2), and model-2 plus gonadotropins and sex steroids (Model-3). Greater $\Delta \mathrm{CD} 4$ count and age were associated with increased osteoporosis after adjusting for different models. Sarcopaenia was observed in $40 \%$ of men and in none of the controls.

Conclusions: Men with decreased skeletal mass, age, severe immune dysfunction at diagnosis, having rapid increase in CD4 count following ART and IRIS have higher risk of osteoporosis in the long run. (Endokrynol Pol 2017; 68 (6): 642-651)
\end{abstract}

Key words: osteoporosis, HIV, skeletal mass, lean mass, fat mass

\section{Streszczenie}

Wstęp: Badanie przeprowadzono w celu oceny częstości występowania oraz czynników predykcyjnych osteoporozy i sarkopenii u mężczyzn zakażonych HIV.

Materiał i metody: Przebadano 220 mężczyzn zakażonych HIV, spośród których u 115 (w wieku 30-50 lat obserwowanych przez rok) wykonano badania hormonalne i dwuenergetyczną absorpcjometrię rentgenowską (dual-energy X-ray absorptiometry, DEXA). Ocenie poddano również 40 osób tworzących grupę kontrolną.

Wyniki: Mężczyźni zakażeni HIV mają istotnie mniejszą gęstość mineralną kości (bone mineral density, BMD) i wartości Z-score w całym szkielecie. Osteoporozę rozpoznano u 64,35\% chorych, a najczęstsze lokalizacje obejmowały całą kość promieniową (49,56\%), 33\% kości promieniowej $(45,21 \%)$, dystalny odcinek kości promieniowej (36,52\%), kręgosłup lędźwiowy $(19,13 \%)$, szyjkę kości udowej (17,39\%), całą kość udową i krętarz większy (7,82\% każde). U pacjentów zakażonych HIV stwierdzono istotnie niższe wartości masy tkanki tłuszczowej (fat mass, FM), masy beztłuszczową (lean mass, LM), całkowitego odsetka tkanki tłuszczowej, zawartości minerałów w kości, tkankę tłuszczową gynoidalną, procentowej masę mięśniowo-szkieletową (percent skeletal muscle mass, PSMM). U mężczyzn z osteoporozą częściej stosowano leczenie przeciwretrowirusowe (anti-retroviral therapy, ART), a także częściej stwierdzano u nich zespół rekonstytucji immunologicznej (immune reconstitution inflammatory syndrome, IRIS), gruźlicę oraz niższe wartości FM, LM i PSMM. Metodą regresji logistycznej wykazano, że najsilniejszymi czynnikami predykcyjnymi osteoporozy były PSMM, wiek i przyrost liczby ( $\Delta$ ) CD4 (zmiana liczby CD4 po 6-12 miesiącach ART w porównaniu z wartościami sprzed ART). Wyższa PSMM wiązała się z mniejszą częstością osteoporozy w następujących modelach: bez korygowania względem jakichkolwiek zmiennych (model-1), po skorygowaniu względem czasu trwania choroby, obecności gruźlicy i IRIS (model-2) oraz model-2 plus gonadotropiny i steroid płciowe (model-3). Większy przyrost liczby limfocytów CD4 i starszy wiek wiązały się dodatnio z występowaniem osteoporozy po skorygowaniu względem różnych modeli. Sarkopenię obserwowano u 40\% chorych z HIV, natomiast nie stwierdzono jej u żadnej osoby z grupy kontrolnej. 
Wnioski: Mężczyźni z obniżoną masą szkieletu, w starszym wieku i z ciężkimi niedoborami immunologicznymi w czasie rozpoznania, u których następuje gwałtowny wzrost liczby limfocytów CD4 po ART i IRIS, cechują się wyższym ryzykiem osteoporozy w perspektywie długoterminowej. (Endokrynol Pol 2017; 68 (6): 643-651)

Słowa kluczowe: osteoporoza, HIV, masa szkieletu, masa beztłuszczowa, masy tkanki tłuszczowej

\section{Introduction}

With the increasing burden of the HIV epidemic, coupled with better outcomes, endocrinopathies are increasingly being encountered in HIV patients [1]. Endocrinopathies are commonly associated with impaired bone health [2,3]. In a meta-analysis, patients with HIV had three-times higher prevalence of low bone mineral density (BMD), compared to controls [4]. Globally, high prevalence of vitamin-D deficiency has been observed in patients with HIV $[5,6]$. Most of the global data on BMD in HIV is available from males, predominantly Caucasians [7]. Most of these studies are limited by a lack of evaluation of representative controls [7].

Alterations in body composition are known to have an impact on bone health in non-HIV infected individuals [8]. A variety of patterns of alterations in lean mass (LM), fat mass (FM), and bone mineral content (BMC) have been reported in HIV [9]. However, bone health and body composition alterations among Indians with HIV has not been evaluated. Hence this study aimed to assess the burden of low BMD (osteoporosis) and determine its predictors in asymptomatic young men with HIV infection.

\section{Material and methods}

The anti-retroviral therapy (ART) clinic at our centre is an apex referral centre, functional since April 2004, established by the National AIDS Control Organisation (NACO) of India and the World Health Organisation (WHO) [1]. Consecutive ambulatory males, 30-50 years of age, with serologically documented HIV infection, in stable clinical condition, without any acute, severe illness, attending the ART clinic, were considered. Men above 30 years of age were only considered for this study because peak bone mass is usually reached by 29 years of age [2]. Also, patients above 50 years of age were excluded to eliminate patients with senile/ /age-related bone loss. Severely ill patients with multiple co-morbid states, which would warrant hospital admission, patients with known endocrinopathies (hypogonadism, hypopituitarism, hypothyroidism, hypocortisolism) were excluded. Patients with a history of hospital admissions in the preceding two months were also excluded. Patient records were reviewed, and those having clinical data of at least one-year followup were further evaluated. Patients with available
CD4 cell counts at diagnosis (pre-HAART) and at first follow-up (6-12 months after diagnosis) were included. The study protocol was explained, and only those who gave informed, written consent were included. The institutional Ethics Committee approved the study protocol. The period of study was from August 2015 until December 2016.

Data were collected regarding duration of HIV infection and details of highly active anti-retroviral therapy (HAART). Data was also collected regarding past or current evidence of opportunistic infections (bacterial, viral, and fungal). Patients underwent detailed clinical assessment, including anthropometry. Patients were called on subsequent days in fasting state for blood sampling. Blood samples of $5 \mathrm{ml}$ each were collected in plain and EDTA vacutainers (Becton Dickinson). Serum was separated from the blood collected in plain vacutainers and processed immediately for routine biochemical analysis, and one aliquot of serum was stored at $-20^{\circ} \mathrm{C}$ for specific immunological (hormonal) assays. The EDTA sample was processed for haematological analysis.

Chemiluminescent microparticle immunoassay (VITROS® ECiQ Immunodiagnostic System, Johnson \& Johnson, USA) was used for estimation of 25-hydroxyvitamin-D (25OHD), prolactin, testosterone, luteinising hormone ( $\mathrm{LH})$, and follicle stimulating hormone (FSH). Serum 25OHD assay had an analytical sensitivity of $19.97 \mathrm{nmol} / \mathrm{L}$, analytical range of $19.97-374.40 \mathrm{nmol} / \mathrm{L}$, and intra and inter-assay coefficient of variation (CV) of $3.4 \%$ and $5.5 \%$, respectively. Testosterone assay had analytical sensitivity of $0.16 \mathrm{mcg} / \mathrm{dl}$, analytical range of $0.17-75.06 \mathrm{nmol} / \mathrm{L}$, and intra and inter-assay $\mathrm{CV}$ of $3.8 \%$ and $7.4 \%$, respectively. LH assay had analytical sensitivity of $0.216 \mathrm{IU} / \mathrm{L}$, analytical range of $0.216-200$ $\mathrm{IU} / \mathrm{L}$, and intra and inter-assay CV of $8.8 \%$ and $11.3 \%$, respectively. FSH assay had analytical sensitivity of $0.66 \mathrm{IU} / \mathrm{L}$, analytical range of $0.66-200 \mathrm{IU} / \mathrm{L}$, and intra and inter-assay CV of $2.8 \%$ and $10.1 \%$, respectively. Serum calcium, phosphate, alkaline phosphate, and renal function tests were done using clinical chemistry auto-analyser based on dry chemistry micro-slide technology (VITROS ${ }^{\circledR} 350$ chemistry system, Johnson \& Johnson, USA). CD4 cell count was performed using flow cytometry (Becton Dickinson Immunocytochemistry Systems, San Jose, CA).

All patients underwent BMD assessment by dualenergy X-ray absorptiometry (DEXA; Discovery Wi 
Series, Serial Number: 84571; Hologic Inc., Waltham, MA) at lumbar spine (LS, L1-L4 anteroposterior), left proximal femur [neck (NOF), greater trochanter (GT) and total femur (TF)], and left forearm regions [radius 33\%, ultra-distal (UD) and radius total]. Quality control procedures were done as per manufacturer's recommendations. A trained technician in the department performed all scans. The instrument was calibrated on a daily basis, using phantom provided by the manufacturer, and the $\mathrm{CV}$ at different sites was found to be $<1.0 \%$ over the duration of the study. The manufacturer's appointed service engineer reviewed the calibration data and performed a scanner maintenance check to ensure the system's performance before, at the beginning, and at the end of the study to confirm that no instrumentation drift occurred during the study period. The BMD of the subjects was recorded in terms of absolute mineral content (in $\mathrm{g} / \mathrm{cm}^{2}$ ) at various sites. Due to significant differences in the ages of patients in the study (30-50 years), Z-score [number of standard deviations (SD) away from average value of age and gender specific reference group] was used to compare BMD across the groups. Osteoporosis at any site was diagnosed if Z-score was $<-2$ SD [10]. T-score was not used for defining osteoporosis because it has been established for diagnosis of osteoporosis in the female postmenopausal state [8].

DEXA was also used for estimation of whole-body bone mineral content $(\mathrm{BMC})(\mathrm{kg})$, total body fat $(\mathrm{kg})$, percentage fat mass (\%), fat mass (FM) $(\mathrm{kg})$, lean mass (LM) (kg), android fat (kg), and gynoid fat (kg). Body composition analyses of soft tissues were performed using QDR2000 product software, version 7.10A (Hologic). The lower border of the android region was set at upper border of pelvis. The upper border of the android region was set at a level being $20 \%$ of the distance from the upper border of the pelvis to the neck. The upper border of the gynoid region was set at the level below the upper border of the pelvis at a distance of 1.5 times the length of the android region. The lower border of the gynoid region was set at the level at which the length of the gynoid region was twice the length of the android region $[1,11]$. The reproducibility of DEXA measurements was derived from the root mean square standard deviation of two repeat measurements $[1,11]$. The technique precision for body composition variables was $12.32 \mathrm{~g}$ for BMC $(0.96 \% \mathrm{CV}), 166.3 \mathrm{~g}$ for LM $(0.74 \% \mathrm{CV})$, and $156.2 \mathrm{~g}$ for FM $(0.72 \% \mathrm{CV})$. Clinical, biochemical, and DEXA parameters were also collected from 40 age-, sex-, and BMI-matched healthy controls, recruited from the nursing staff of the institute, who had given informed written consent.
Sarcopaenia has been defined as progressive and generalised loss of skeletal muscle mass and strength, associated with increased morbidity and mortality [12]. Documenting low muscle mass is an important component of assessing sarcopaenia. The percentage of skeletal muscle mass (PSMM) (total lean mass/weight $x$ 100) was calculated in patients and controls [12]. Low skeletal mass volume (PSMM) has been used to define sarcopaenia [12]. Due to lack of normative date from the India population, according to the European Working Group on Sarcopaenia in Older People recommendations, a PSMM of $<2$ SD below the mean in the healthy control group was used to define sarcopaenia [13]. Studies have shown that PSMM provides a better and higher estimation of sarcopaenia when DEXA is used as a tool for assessment $[12,13]$.

Immune reconstitution inflammatory syndrome (IRIS) in HIV-infected patients is characterised by clinical deterioration secondary to re-establishment of immunity following HAART [14]. It is usually observed in patients with low baseline CD4 count, which increases rapidly following HAART initiation. HAART has been linked to increased systemic inflammation and autoimmunity [14, 15]. IRIS has been defined as CD4 count $>200$ cells $/ \mathrm{mm}^{3}$ in patients who previously had CD4 counts $<100-200$ cells $/ \mathrm{mm}^{3}$ [16]. Hence patients in our study with baseline CD4 counts < 200 cells $/ \mathrm{mm}^{3}$, which increased to $>200$ cells $/ \mathrm{mm}^{3}$ at first follow-up following HAART initiation, were defined as having IRIS.

\section{Results}

A total of 220 consecutive males with HIV were screened, of which 115 who fulfilled all criteria and gave consent underwent hormonal and DEXA analysis (Figure 1). In addition, 40 healthy age-, sex-, and BMI-matched controls underwent the same set of investigations. The median age of our patients with HIV infection was 40 years, having median disease duration of 38 months, with $90.43 \%$ on HAART, $35.65 \%$ having history of tuberculosis, $51.3 \%$ having history of IRIS, and 93.05\% patients having vitamin-D deficiency/ /insufficiency (Table I). Males with HIV had significantly lower BMD and corresponding Z-scores at all the sites evaluated (LS, TF, NOF, greater trochanter, radius total, radius UD, and radius 33\%), as compared to controls (Table II). Osteoporosis involving at least any one site was observed in $74(64.35 \%)$ males with HIV as compared to six (15.00\%) individuals in the control group $(\mathrm{P}<0.001)$. The most common site of osteoporosis among HIV-infected males was radius total $(49.56 \%$; $\mathrm{n}=57)$, followed by radius $33 \%(45.21 \% ; \mathrm{n}=52)$, radius $\mathrm{UD}(36.52 \% ; \mathrm{n}=42), \mathrm{LS}(19.13 \% ; \mathrm{n}=22)$, NOF $(17.39 \%$; 
STUDY POPULATION: 220 consecutive males with HIV infection were screened at the ART clinic

INCLUSION CRITERIA: age 30-50 years, stable, ambulatory

EXCLUSION CRITERIA: severely ill $(n=17)$, multiple comorbid states like chronic liver disease, chronic kidney disease $(n=15)$, endocrinopathies (hypogonadism, hypopituitarism, hyperthyroidism) $(n=14)$, history of hospital admission in last 2 months $(n=11)$, active tuberculosis

on anti-tubercular therapy $(n=4)$

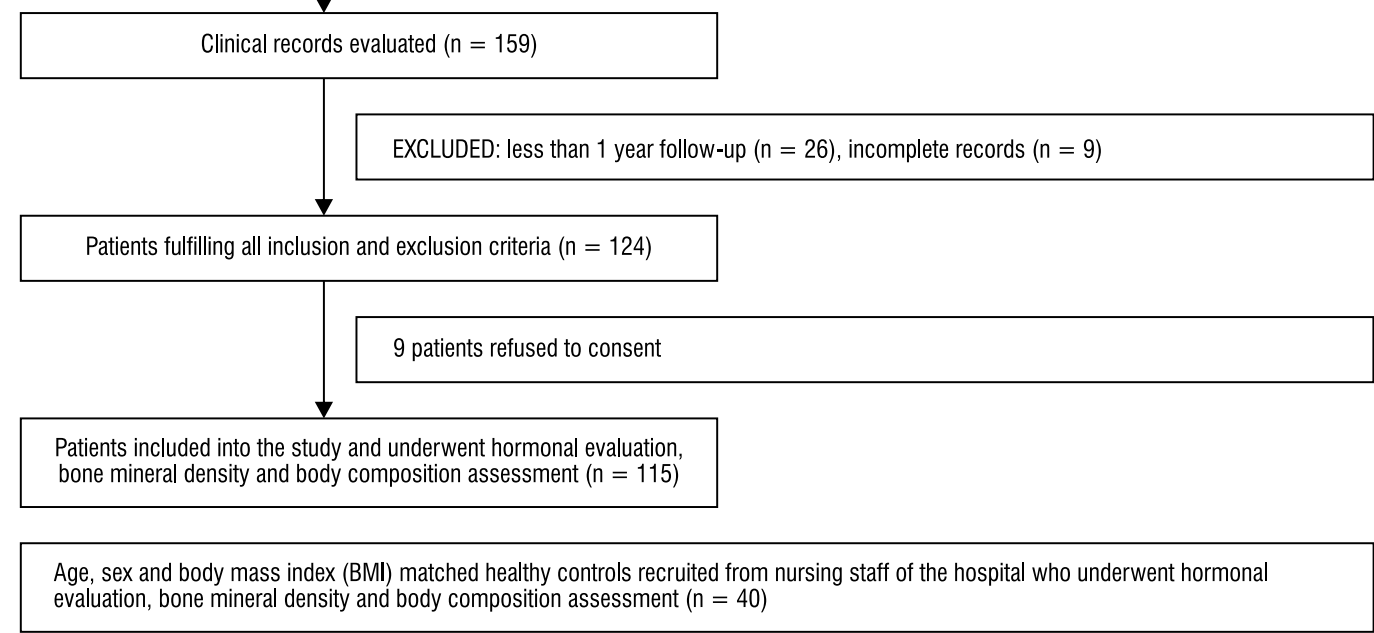

Figure 1. Flowchart elaborating the study protocol and flow of patients

Rycina 1. Schemat przedstawiający przebieg badania wśród pacjentów

$\mathrm{n}=20)$, total femur, and greater trochanter $(7.82 \%$ $\mathrm{n}=9$ each) (Table II). Patients with HIV had significantly lower total fat mass $(\mathrm{P}<0.001)$, LM $(\mathrm{P}=0.024)$, total fat percentage $(\mathrm{P}<0.001)$, BMC $(\mathrm{P}=0.039)$, gynoid fat $(\mathrm{P}<0.001)$, and PSMM $(\mathrm{P}=0.05)$, as compared to controls (Table II).

Among males with HIV, those with osteoporosis had higher use of HAART $(\mathrm{P}=0.007)$, higher history of IRIS $(\mathrm{P}=0.049)$ and tuberculosis $(\mathrm{P}=0.056$; approached statistical significance), and lower FM $(\mathrm{P}=0.006), \mathrm{LM}(\mathrm{P}=0.012)$, and PSMM( $(\mathrm{P}=0.004)$ (TableIII). Binary logistic regression analysis revealed that PSMM, age, and delta $(\Delta)$ CD4 count (change in CD4 count at 6-12-month follow-up with regard to CD4 cell count at diagnosis) were consistently the best predictors of occurrence of osteoporosis. A greater PSMM was associated with decreased osteoporosis risk, without adjusting for any variable (Model 1), after adjusting for disease duration, history of tuberculosis, and IRIS (Model 2), and after adjusting for variables in Model 2 plus LH, FSH, oestradiol, and testosterone (Model 3) (Table IV). A greater increment in CD4 count ( $\triangle$ CD4 count) was associated with increased risk of osteoporosis after adjusting for Model 1 and Model 3. Increased age was associated with increased risk of osteoporosis after adjusting for variables in Model 2 and 3 (Table IV).

PSMM in controls and males with HIV was 67.08 $\pm 4.11 \%$ and $63.74 \pm 10.66 \%$, respectively $(\mathrm{P}=0.05)$. $\mathrm{PSMM}<58.86 \%$ (2 SD lower than the mean in controls) was defined as sarcopaenia (vide supra) [11]. Using this definition, sarcopaenia was observed in 46 males (40\%) with HIV infection but in none of the control individuals. 35 out of 74 HIV males with osteoporosis (47.29\%) had sarcopaenia, in contrast to 11 out of 41 males without osteoporosis $(26.83 \%)(\mathrm{P}=0.029) .64 .35 \%$ of patients in the HIV group $(\mathrm{n}=115)$ had osteoporosis, in contrast to $15 \%$ in the control group $(\mathrm{n}=40)$. This evaluation achieved $>99.9 \%$ power, keeping type-I error (alpha) at $5 \%$.

\section{Discussion}

Bone mineral (BM) loss in HIV is multifactorial. Immune dysregulation and systemic inflammation (increased circulating levels of cytokines viz. tumour necrosis factor alpha and interleukins, among others) play a role in increased receptor activator of nuclear factor kappa B (RANK) ligand secretion from osteoblasts, along with increased RANK expression on osteoclasts, leading to osteoclast activation and suppression of osteoblasts [17]. HIV viral proteins (vpr and gp120) promote osteoclast activity, and p55-gag suppresses osteoblast activity, in-vitro [18]. Malnutrition, underweight, physical inactivity, malabsorption, hypogonadism, glucocorticoids, vitamin-D deficiency, substance abuse, and smoking all contribute to BM loss in HIV [17]. The HIV-infected patients in our study had a high prevalence of vitamin-D deficiency/insufficiency, reflective of high vitamin-D deficiency state in the 
Table I.Clinical, demographic, and immunological characteristics of HIV-infected men in this study

Tabela I.Parametry kliniczne, demograficzne i immunologiczne u mężczyzn zakażonych HIV uczestniczących w badaniu

\begin{tabular}{|c|c|c|}
\hline \multicolumn{2}{|l|}{ Parameter } & Patients $(n=115)$ \\
\hline \multicolumn{2}{|l|}{ Age (years) ${ }^{\mathrm{a}}$} & $40[34-44]$ \\
\hline \multicolumn{2}{|c|}{ Duration of HIV infection (months) ${ }^{\mathrm{a}}$} & 38 [21-77] \\
\hline \multicolumn{2}{|l|}{ HAART } & $104(90.43 \%)$ \\
\hline \multirow[t]{3}{*}{ Nature of HAART } & NRTI & $103(89.56 \%)$ \\
\hline & NNRTI & $103(89.56 \%)$ \\
\hline & $\mathrm{PI}$ & $2(1.74 \%)$ \\
\hline \multicolumn{2}{|l|}{$\mathrm{H} / \mathrm{o}$ tuberculosis } & $41(35.65 \%)$ \\
\hline \multicolumn{2}{|c|}{ H/o opportunistic fungal infection } & $1(0.87 \%)$ \\
\hline \multicolumn{2}{|l|}{$\mathrm{H} / \mathrm{o}$ viral infection* } & $2(1.74 \%)$ \\
\hline \multicolumn{2}{|l|}{ IRIS } & $59(51.30 \%)$ \\
\hline \multicolumn{2}{|l|}{ BMI $\left(\mathrm{kg} / \mathrm{m}^{2}\right)$} & 21.61 [19.53-24.93] \\
\hline \multicolumn{2}{|c|}{ CD4 cell count (at diagnosis) $\left(\text { cell/ } / \mathrm{mm}^{3}\right)^{\mathrm{a}}$} & 143 [114-230] \\
\hline \multicolumn{2}{|c|}{$\begin{array}{l}\text { CD4 cell count (6-12 month after diagnosis) } \\
\left(\text { cell/ } / \mathrm{mm}^{3}\right)^{\mathrm{a}}\end{array}$} & $275[218-378]$ \\
\hline \multicolumn{2}{|c|}{ CD4 cell count (at present) (cell/ $\left./ \mathrm{mm}^{3}\right)^{\mathrm{a}}$} & $377[252-494]$ \\
\hline \multicolumn{2}{|l|}{ Haemoglobin (g/L) } & 12.99 [11.72-14.15] \\
\hline \multicolumn{2}{|c|}{ Total leucocyte count $\left(\text { cells } / \mathrm{mm}^{3}\right)^{\mathrm{a}}$} & $6400[5430-8000]$ \\
\hline \multicolumn{2}{|c|}{ Erythrocytic sedimentation rate $(\mathrm{mm} / \mathrm{hr})^{\mathrm{a}}$} & $18[6-26]$ \\
\hline \multicolumn{2}{|l|}{ Creatinine (mg/dl) } & $0.7[0.6-0.9]$ \\
\hline \multicolumn{2}{|c|}{ Serum glutamic-pyruvic transaminase (IU/L) ${ }^{a}$} & 34 [23-58] \\
\hline \multicolumn{2}{|c|}{ Total cholesterol $(\mathrm{mmol} / \mathrm{L})^{\mathrm{a}}$} & 5 [3.99-5.46] \\
\hline \multicolumn{2}{|c|}{ Triglycerides $(\mathrm{mmol} / \mathrm{L})^{\mathrm{a}}$} & $1.75[1.38-2.26]$ \\
\hline \multicolumn{2}{|c|}{ Luteinizing hormone (IU/L)(1.4-9.2) ${ }^{\mathrm{a}}$} & $5.3[3.5-7.6]$ \\
\hline \multicolumn{2}{|c|}{ Follicle stimulating hormone (IU/L) (1.6-10.8) } & $5.35[4.01-7.43]$ \\
\hline \multicolumn{2}{|c|}{ Oestradiol $(\mathrm{pmol} / \mathrm{L})(72.36-242)^{\mathrm{a}}$} & $88.21[71.91-100.29]$ \\
\hline \multicolumn{2}{|c|}{ Testosterone $(\mathrm{nmol} / \mathrm{L})(8.68-34.70)^{\mathrm{a}}$} & 11.24 [8.94-15.79] \\
\hline \multicolumn{2}{|c|}{ Prolactin $(\mathrm{pmol} / \mathrm{L})(<870)^{\mathrm{a}}$} & $452.17[358-817.39]$ \\
\hline \multirow{4}{*}{$\begin{array}{l}\text { Serum 250HD } \\
\text { status }\end{array}$} & $<25 \mathrm{nmol} / \mathrm{L}$ & 5 (4.35\%) \\
\hline & $25-50 \mathrm{nmol} / \mathrm{L}$ & $58(50.43 \%)$ \\
\hline & $50-75 \mathrm{nmol} / \mathrm{L}$ & $44(38.26 \%)$ \\
\hline & $\geq 75 \mathrm{nmol} / \mathrm{L}$ & 8 (6.95\%) \\
\hline
\end{tabular}

All continuous variables expressed as mean (standard deviation); aall non-normally distributed variable expressed as median [range]; all discreet variables have been expressed as absolute numbers (percentage); anot normally distributed; normality checked using Kolmogorov-Smirnov test; $\mathrm{P}<0.05$ considered statistically significant; \#P-value calculated using Chi-square test:* viral infections include hepatitis- $B$, hepatitis- $C$, and others HAART — highly active anti retro-viral therapy; NRTI — nucleoside reverse transcriptase inhibitors; NNRTI: non-nucleoside reverse transcriptase inhibitor; $\mathrm{PI}$ — protease inhibitors; zidovudine (AZT), lamivudine (3TC), stavudine (d4T) and/or tenofovir (TDF) were the NRTIs received by the patients; nevirapine (NVP) or efavirinez (EFV) were the NNRTIs received by the patients; atazanavir (ATV) or ritonavir (RTV) were the Pls received by the patients; IRIS - immune reconstitution inflammatory syndrome

general population $[19,20]$. Vitamin-D deficiency, as well as its classical role in calcium absorption and bone formation, has been linked with increased systemic inflammation, immune dysfunction, autoimmunity, and secondary hyperparathyroidism, which may further accentuate bone loss [21, 22].

In an abstract presented at the 2014 annual conference of the International AIDS Society (the only previous report from India), Dravid et al. reported $29.6 \%$ and $36.6 \%$, respectively, HAART naïve $(n=40)$ and on HAART patients $(n=496)$ to have osteoporosis [23]. However, details from that study are not available. In contrast, the burden of osteoporosis (at any one site) among young men with HIV is much higher $(64.35 \%$ patients) in our study, predominantly involving the wrists (36-49\%), and much lower at the spine and hip (7-19\%). The high prevalence of vitamin-D may contribute to the increased bone loss at wrists observed in our study (due to associated secondary hyperparathyroidism, which is well known to predominantly effect the peripheral/wrist BMD) [2]. However, serum intact parathyroid hormone levels were not evaluated in this study, which is a limitation.

Our study demonstrated that decreased skeletal mass (PSMM) was the strongest and best predictor of osteoporosis in males with HIV. Skeletal mass is the predominant component of lean mass in the body, which results in more mechanical loading of the body, thus having a positive impact on bone mass [24, 25]. Skeletal muscles in addition cause dynamic loading of the muscles. Bone adapts more to dynamic muscle load than to static load, explaining the stronger effect of skeletal mass (lean mass) over BMD, as compared to fat mass [26]. This also explains the beneficial effect of physical activity on bone health, which is associated with better skeletal mass, and decreased falls, thus deceasing fracture risk $[25,26]$. Sarcopaenia is a measure of decreased muscular volume and function. Sarcopaenia was observed in $40 \%$ of males with HIV infection but in none of the controls individuals, which further highlights the link between muscle mass and bone mineral loss. Poor nutrition, increased systemic inflammation, hormonal alterations, and neuromuscular and mitochondrial dysfunction (myopathy, polyneuropathy, wasting syndrome) are some of the factors responsible for sarcopenia in HIV [27-32]. A study in males with HIV infection from Cleveland, USA also documented a high prevalence of low BMD $(68.2 \%)$ and sarcopaenia (21.9\%) [33]. In that study, loss of LM was seen, with an accompanying increase in central fat accumulation and peripheral fat atrophy in HIV patients, as compared to controls [33]. The term, "sarco-osteoporosis" is increasingly being used to highlight the impact of the neuromuscular system on bone health and osteoporotic fractures [34, 35].

After PSMM, $\triangle \mathrm{CD} 4$ cell count (change in CD4 cell count at 6-12 months after HAART initiation with regards to pre-HAART CD4 cell count levels) was 
Table II. Clinical, calcium metabolism profile, bone mineral density, and body composition profile of males with HIV infection as compared to healthy controls

Tabela II. Parametry kliniczne, metabolizm wapnia, gęstość mineralna kości i skład ciała u mężczyzn zakażonych HIV w porównaniu z osobami z grupy kontrolnej

\begin{tabular}{|c|c|c|c|}
\hline Parameter & Males with HIV $(n=115)$ & Healthy controls $(n=40)$ & P-value \\
\hline Age (years) ${ }^{\mathrm{a}}$ & $40[34-44]$ & 39 [32.5-41] & 0.147 \\
\hline BMI $\left(\mathrm{kg} / \mathrm{m}^{2}\right)$ & $21.78 \pm 5.19$ & $22.95 \pm 3.14$ & 0.169 \\
\hline Calcium $(\mathrm{mmol} / \mathrm{L})$ & $2.31 \pm 0.14$ & $2.33 \pm 0.14$ & 0.601 \\
\hline $\operatorname{ALP}(\mu \mathrm{kat} / \mathrm{L})$ & $2.07 \pm 0.73$ & $2.33 \pm 0.80$ & 0.650 \\
\hline $250 \mathrm{HD}(\mathrm{nmol} / \mathrm{L})$ & $47.97 \pm 15.95$ & $51.54 \pm 11.68$ & 0.195 \\
\hline $\mathrm{BMD}(\mathrm{L} 1-\mathrm{L} 4)\left(\mathrm{g} / \mathrm{cm}^{2}\right)^{\mathrm{a}}$ & $0.945[0.888-1.006]$ & $0.984[0.954-1.060]$ & $<0.001$ \\
\hline Z-Score (L1-L4) ${ }^{\mathrm{a}}$ & -1.1 [from -1.8 to -0.5 ] & -0.85 [from -1.07 to -0.25 ] & 0.002 \\
\hline Osteoporosis (L1-L4) & 22 & 0 & $<0.001$ \\
\hline BMD total femur $\left(\mathrm{g} / \mathrm{cm}^{2}\right)^{\mathrm{a}}$ & $0.938[0.817-1.041]$ & 1.061 [0.981-1.129] & $<0.001$ \\
\hline Z-score total femura & -0.4 [from -1.1 to 0.2 ] & $0.5[-0.2-1.00]$ & $<0.001$ \\
\hline Osteoporosis total femur & 9 & 0 & $<0.001$ \\
\hline BMD NOF $\left(\mathrm{g} / \mathrm{cm}^{2}\right)^{\mathrm{a}}$ & $0.719[0.635-0.836]$ & $0.831[0.754-0.983]$ & $<0.001$ \\
\hline Z-score NOFa & -1.1 [from -1.65 to -0.2 ] & -0.2 [from -0.88 to 0.50 ] & $<0.001$ \\
\hline Osteoporosis NOF & 20 & 0 & $<0.001$ \\
\hline BMD greater trochanter $\left(\mathrm{g} / \mathrm{cm}^{2}\right)^{\mathrm{a}}$ & $0.661[0.581-0.725]$ & $0.726[0.680-0.813]$ & $<0.001$ \\
\hline Z-score greater trochantera & -0.7 [from -1.33 to -0.2 ] & -0.2 [from -0.48 to 0.30 ] & $<0.001$ \\
\hline Osteoporosis greater trochanter & 9 & 0 & $<0.001$ \\
\hline BMD radius total $\left(\mathrm{g} / \mathrm{cm}^{2}\right)^{\mathrm{a}}$ & $0.547[0.497-0.607]$ & $0.588[0.554-0.631]$ & 0.002 \\
\hline Z-score radius totala & -21 . [from -2.73 to -0.9 ] & -1.15 [from -2.05 to -0.50 ] & 0.028 \\
\hline Osteoporosis radius total & 57 & 6 & $<0.001$ \\
\hline BMD radius $U D\left(\mathrm{~g} / \mathrm{cm}^{2}\right)^{\mathrm{a}}$ & $0.394[0.373-0.461]$ & $0.496[0.462-0.616]$ & $<0.001$ \\
\hline Z-score radius UDa & -1.4 [from -2.2 to -0.2 ] & -0.40 [from -0.85 to 1.52 ] & $<0.001$ \\
\hline Osteoporosis radius UD & 42 & 0 & $<0.001$ \\
\hline BMD radius $(33 \%)\left(\mathrm{g} / \mathrm{cm}^{2}\right)^{\mathrm{a}}$ & $0.695[0.642-0.747]$ & $0.677[0.589-0.743]$ & 0.005 \\
\hline Z-score radius $(33 \%)^{\mathrm{a}}$ & -1.9 [from -2.6 to -0.9 ] & -1.1 [from -2.2 to -0.30$]$ & 0.200 \\
\hline Osteoporosis radius $(33 \%)$ & 52 & 5 & $<0.001$ \\
\hline Total fat mass $(\mathrm{kg})^{\mathrm{a}}$ & 13.635 [11.813-17.738] & 18.119 [15.669-22.686] & $<0.001$ \\
\hline Total lean mass $(\mathrm{kg})^{\mathrm{a}}$ & 42.528 [38.660-47.855] & 47.532 [43.947-49.843] & 0.024 \\
\hline Total bone mineral content $(\mathrm{kg})^{\mathrm{a}}$ & 2.009 [1.878-2.282] & $2.531[2.088-2.817]$ & 0.039 \\
\hline Total fat percentage $(\%)^{a}$ & 24.8 [19.6-27.3] & $27.6[24.3-30.8]$ & $<0.001$ \\
\hline Android fat $(\mathrm{kg})^{\mathrm{a}}$ & $1.425[1.106-2.044]$ & $1.705[1.202-2.067]$ & 0.969 \\
\hline Gynoid fat $(\mathrm{kg})^{\mathrm{a}}$ & $1.830[1.441-2.228]$ & 3.168 [2.903-3.504] & 0.005 \\
\hline Android/gynoid ratioa & $0.798[0.542-0.992]$ & $0.509[0.422-0.634]$ & 0.759 \\
\hline PSMMa & 64 [54-73.49] & 68.61 [63.37-70.85] & 0.050 \\
\hline
\end{tabular}

consistently the second-best predictor of osteoporosis after adjusting for various variables. A greater $\Delta \mathrm{CD} 4$ count was associated with increased osteoporosis. A greater $\Delta C D 4$ count implies that the patient has a more severe immunodeficiency at the disease onset (lower pre-HAART CD4 count), explaining the greater increase in CD4 count post HAART (better improvement in immune function). Such a CD4 count response is typically associated with higher occurrence of IRIS. Indeed, the occurrence of IRIS was higher in HIV males with osteoporosis as compared to those without osteoporosis in our study. A more severe immunodeficiency at disease 
Table III. Clinical, biochemical, body composition, and bone mineral density (BMD) profile of HIV-infected males with osteoporosis at any site as compared to those having normal BMD at all sites

Tabela III. Parametry kliniczne i biochemiczne, skład ciała i gęstość mineralna kości (bone mineral density, BMD) u mężczyzn zakażonych HIV z osteoporozq̨ o jakiejkolwiek lokalizacji w porównaniu z osobami majq̨cymi prawidłowq BMD we wszystkich lokalizacjach

\begin{tabular}{|c|c|c|c|}
\hline Parameter & $\begin{array}{l}\text { HIV males with osteoporosis } \\
(\mathrm{n}=74)\end{array}$ & $\begin{array}{l}\text { HIV with normal BMD } \\
(\mathrm{n}=41)\end{array}$ & P-value \\
\hline Age (years) ${ }^{\mathrm{a}}$ & $41[35-47]$ & $35.5[31-40]$ & 0.006 \\
\hline BMI $\left(\mathrm{kg} / \mathrm{m}^{2}\right)$ & $22 \pm 4.90$ & $21.76 \pm 5.97$ & 0.821 \\
\hline $\mathrm{H} / \mathrm{o}$ tuberculosis & 31 & 10 & 0.056 \\
\hline IRIS & 43 & 16 & 0.049 \\
\hline HAART & 71 & 33 & 0.007 \\
\hline Duration of diagnosis (months) & 39 [19-85] & 36 [24-64] & 0.289 \\
\hline Calcium (mmol/L) & $2.32 \pm 0.15$ & $2.32 \pm 0.23$ & 0.963 \\
\hline $\operatorname{ALP}(\mu \mathrm{kat} / \mathrm{L})$ & $1.95 \pm 0.59$ & $2.30 \pm 0.79$ & 0.071 \\
\hline $250 \mathrm{HD}(\mathrm{nmol} / \mathrm{L})$ & $47.95 \pm 14.58$ & $50.02 \pm 18.50$ & 0.522 \\
\hline BMD (L1-L4) $\left(\mathrm{g} / \mathrm{cm}^{2}\right)^{\mathrm{a}}$ & $0.925[0.795-0.970]$ & 1.004 [0.954-1.073] & $<0.001$ \\
\hline Z-Score (L1-L4) ${ }^{\mathrm{a}}$ & -1.3 [from -2.3 to -1.0 ] & -0.4 [from -1.1 to 0.2 ] & $<0.001$ \\
\hline BMD total femur $\left(\mathrm{g} / \mathrm{cm}^{2}\right)^{\mathrm{a}}$ & $0.864[0.802-0.973]$ & $1.041[0.953-1.128]$ & $<0.001$ \\
\hline Z-score total femura & -0.95 [from -1.42 to -0.2 ] & 0.3 [from -0.5 to 0.9 ] & $<0.001$ \\
\hline BMD NOF $\left(\mathrm{g} / \mathrm{cm}^{2}\right)^{\mathrm{a}}$ & $0.655[0.594-0.784]$ & $0.845[0.761-0.962]$ & $<0.001$ \\
\hline Z-score NOFa & -1.2 [from -1.9 to -0.4$]$ & 0.15 [from -1.10 to 0.575 ] & $<0.001$ \\
\hline BMD greater trochanter $\left(\mathrm{g} / \mathrm{cm}^{2}\right)^{\mathrm{a}}$ & $0.642[0.556-0.669]$ & $0.742[0.715-0.840]$ & $<0.001$ \\
\hline Z-score greater trochantera & -0.8 [from -1.55 to -0.60 ] & -0.1 [from 0.4 to 0.725 ] & $<0.001$ \\
\hline $\mathrm{BMD}$ radius total $\left(\mathrm{g} / \mathrm{cm}^{2}\right)^{\mathrm{a}}$ & $0.532[0.491-0.560]$ & 0.649 [0.592-0.659] & $<0.001$ \\
\hline Z-score radius totala & $-2.6[$ from -3.25 to -2.1$]$ & -0.25 [from -0.9 to 0.00$]$ & $<0.001$ \\
\hline $\mathrm{BMD}$ radius $\mathrm{UD}\left(\mathrm{g} / \mathrm{cm}^{2}\right)^{\mathrm{a}}$ & $0.381[0.360-0.407]$ & $0.463[0.416-0.503]$ & $<0.001$ \\
\hline Z-score radius $\mathrm{UDa}$ & -2.0 [from -2.3 to -1.4$]$ & -0.2 [frem -0.8 to 0.00 ] & $<0.001$ \\
\hline BMD radius $(33 \%)\left(\mathrm{g} / \mathrm{cm}^{2}\right)^{\mathrm{a}}$ & $0.671[0.625-0.703]$ & $0.752[0.703-0.816]$ & $<0.001$ \\
\hline Z-score radius $(33 \%)^{\mathrm{a}}$ & -2.3 [from -2.8 to -1.9$]$ & -0.7 [from -1.1 to 0.325$]$ & $<0.001$ \\
\hline Total fat mass $(\mathrm{kg})^{\mathrm{a}}$ & $13.635[11.281-15.894]$ & $14.265[11.866-26.260]$ & 0.006 \\
\hline Total lean mass $(\mathrm{kg})^{\mathrm{a}}$ & 40.14 [38.03-46.82] & $46.296[40.201-47.855]$ & 0.012 \\
\hline Total bone mineral content $(\mathrm{kg})^{\mathrm{a}}$ & $1.950[1.841-2.262]$ & $2.188[2.102-2.367]$ & 0.001 \\
\hline Total fat percentage $(\%)^{\text {a }}$ & $23.95[19.3-26.90]$ & 23.9 [19.6-29.65] & 0.278 \\
\hline Android fat $(\mathrm{kg})^{\mathrm{a}}$ & $1.43[1.10-1.90]$ & 1.49 [1.065-2.464] & 0.714 \\
\hline Gynoid fat $(\mathrm{kg})^{\mathrm{a}}$ & $1.80[1.44-2.15]$ & $1.961[1.515-3.111]$ & 0.713 \\
\hline Android/gynoid ratioa & $0.75[0.54-1.00]$ & $0.813[0.601-0.877]$ & 0.657 \\
\hline PSMM $^{a}$ & $60.43[52-70.97]$ & 66.70 [61.23-77.32] & 0.004 \\
\hline CD4 cell count (at diagnosis) $\left(\text { cell/ } / \mathrm{mm}^{3}\right)^{\mathrm{a}}$ & 142 [107-201] & 162 [122-280] & 0.479 \\
\hline CD4 cell count (6-12 month after diagnosis) $\left(\text { cell } / \mathrm{mm}^{3}\right)^{\mathrm{a}}$ & $317[220-385]$ & $273[217-357]$ & 0.121 \\
\hline CD4 cell count (at present) $\left(\text { cell } / \mathrm{mm}^{3}\right)^{\mathrm{a}}$ & 389 [290-523] & 367 [229-447] & 0.168 \\
\hline $\mathrm{LH}(\mathrm{IU} / \mathrm{L})(1.4-9.2)^{\mathrm{a}}$ & $4.62[3.26-6.95]$ & $5.63[3.76-8.87]$ & 0.047 \\
\hline FSH (IU/L) (1.6-10.8) ${ }^{\mathrm{a}}$ & $5.54[4.12-7.26]$ & $5.38[4.07-7.55]$ & 0.184 \\
\hline Oestradiol (pmol/L) $(19.71-242)^{\mathrm{a}}$ & $92.98[71.29-99.14]$ & 92.69 [68.39-97.02] & 0.697 \\
\hline Testosterone $(\mathrm{nmol} / \mathrm{L})(8.68-34.70)^{\mathrm{a}}$ & $11.40[8.80-16.30]$ & $10.34[7.13-13.70]$ & 0.125 \\
\hline Prolactin $(\mathrm{pmol} / \mathrm{L})(<870)^{\mathrm{a}}$ & $443.5[339.13-679.56]$ & $495.65[350.43-665.21]$ & 0.719 \\
\hline
\end{tabular}

250HD — 25-hydroxy-vitamin-D; ALP — alkaline phosphate; BMD: bone mineral density; IRIS: immune reconstitution inflammatory syndrome; L1-L4 — lumbar spine L1 to L4; NOF — neck of femur; PSMM — percentage skeletal muscle mass; normality of variable distribution checked using Kolmogorov-Smirnov test; normally distributed variables expressed as mean \pm standard deviation; ${ }^{\text {a }}$ all non-normally distributed variable expressed as median $\left[25-75^{\text {th }}\right.$ percentile]; $\mathrm{P}$-value calculated using unpaired t-test; $\mathrm{P}<0.05$ considered statistically significant 
Table IV. Binary logistic regression analysis showing factors that independently predict the occurrence of osteoporosis at any site in males with HIV infection

Tabela IV. Niezależne czynniki predykcyjne występowania osteoporozy w jakiejkolwiek lokalizacji u mężczyzn zakażonych HIV na podstawie analizy binarnej regresji logistycznej

\begin{tabular}{lllllllllll}
\hline & Model-1 & \multicolumn{3}{c}{ Model-2 } & \multicolumn{3}{c}{ Model-3 } \\
\hline Variable & $\mathrm{B}$ & Exp (B) & P-value & $\mathrm{B}$ & Exp (B) & P-value & $\mathrm{B}$ & Exp (B) & P-value \\
\hline Age & 0.057 & 1.059 & 0.091 & 0.072 & 1.075 & 0.048 & 0.086 & 1.090 & 0.030 \\
\hline BMl & 0.053 & 1.054 & 0.407 & 0.049 & 1.051 & 0.463 & 0.063 & 1.065 & 0.355 \\
\hline$\Delta$ CD4 Count & 0.004 & 1.004 & 0.045 & 0.004 & 1.004 & 0.054 & 0.006 & 1.006 & 0.032 \\
\hline Total lean mass & -0.00004 & 0.9999 & 0.315 & -0.0003 & 0.9999 & 0.398 & -0.00002 & 0.9999 & 0.561 \\
\hline Total fat mass & -0.00006 & 0.9999 & 0.210 & -0.0005 & 0.9999 & 0.321 & -0.00005 & 0.9999 & 0.380 \\
\hline PSMM & -0.056 & 0.945 & 0.031 & -0.062 & 0.940 & 0.023 & -0.066 & 0.936 & 0.018 \\
\hline
\end{tabular}

Binary logistic regression was initially performed with all parameters likely to influence the occurrence of osteoporosis [age, body mass index (BMI), duration of HIV infection, baseline CD4 count, delta $(\Delta)$ CD4 count (change in CD4 count at 6-12-month follow-up with regards to CD4 cell count at diagnosis (baseline)), serum 25-hydroxy-vitamin-D (25OHD), oestradiol, DHEAS, testosterone, follicle stimulating hormone (FSH), luteinising hormone (LH), total lean mass, total fat mass, android (A) fat, Gynoid (G) fat, A/G ratio, percentage skeletal muscle mass (PSMM), history of tuberculosis, opportunistic fungal infections, viral infections (hepatitis-B and hepatitis-C), and individual anti retro-viral agents received by the patient]. Parameters with $p<0.2$ were included into the final model as elaborated in the table; $\operatorname{Exp}(B)$ : exponentiation of the B coefficient, change in odds ratio with one unit change in predictor variable; for categorical variables, history of tuberculosis and nucleoside reverse transcriptase inhibitors (NRTI) use, absence of tuberculosis and absence of NRTI use were taken as reference group; Model 1: without adjustment for any variables; Model 2: after adjustment for duration of HIV infection, history of tuberculosis and IRIS; Model 3: after adjustment for variables in Model 2 plus LH, $\mathrm{FSH}$, oestradiol, and testosterone levels

onset, greater $\triangle \mathrm{CD} 4$ count, and IRIS are associated with higher systemic inflammation, which may contribute to BM loss. Grant PM et al. observed a lower baseline CD4 count to be associated with greater BMD loss in first two years following HAART [31].

In addition, HAART in general is believed to contribute to osteoporosis [26]. In our study also, patients with osteoporosis had higher use of HAART as compared to those without osteoporosis. HAART is believed to induce marked BMD loss (2-6\%) within the first two years, irrespective of antiretroviral agent used [27]. IRIS may have a role in this early HAART-related bone loss [28]. Protease inhibitors and tenofovir have been most commonly linked to BM loss [28]. Tenofovir, through proximal renal tubular toxicity, causes renal phosphate wasting, explaining BM loss [28, 29]. However, in our study, no specific anti-retroviral agent was linked to osteoporosis. Increased age was associated with increased osteoporosis after adjusting for variables in Model 2 and 3. This can be explained by the physiological age-related bone mineral loss in all individuals after the attainment of peak bone mass [2, 8].

There are limited data on therapeutic outcomes in HIV-associated osteoporosis. Apart from bisphosphonates, no other agent has been evaluated in HIV-associated osteoporosis. Alendronate over a period of 96 weeks has been documented to improve BMD in patients on HAART [36]. In another randomised controlled trial, two annual doses of $4 \mathrm{mg}$ zoledronic acid was demonstrated to have a beneficial effect on BMD, which persisted for at least five years after the second dose [37].
Limitations of this study include its cross-sectional design. Also, visceral and subcutaneous fat could not be assessed separately because DEXA and not computed tomography was used for body composition analysis. Strengths of this study include the evaluation of a relatively large homogenous cohort of young HIV-infected men, with matched healthy controls, a cohort that has been less evaluated, and one in which bone health assessment would be more meaningful because early therapeutic interventions can improve long-term outcomes.

To conclude, this study highlights the unrecognized significant burden of osteoporosis (64\%) and sarcopaenia $(40 \%)$ in young Indian men with HIV infection. Evaluation of sarcopaenia has an important role in predicting low BMD and osteoporosis in HIV. This study highlights the importance of adequate skeletal mass, and hence daily exercise and physical activity in maintaining bone health. Men with more severe immune dysfunction at diagnosis, who were probably sicker, with lower CD4 counts at diagnosis, and having a more rapid increase in CD4 count following HAART, and having history of IRIS have higher risk of osteoporosis in the long run.

\section{Acknowledgements}

The authors are grateful to the staff of the department of Endocrinology, Radiology, and Biochemistry for their assistance in making this work possible. The authors are also grateful to all the patients and nursing staff of the hospital for their support and cooperation. 


\section{Funding}

This study was funded by the annual research grant of the Indian Society of Bone and Mineral Research (ISBMR) for the year 2015-2016.

\section{Conflict of interests}

None

\section{Authors' contribution}

DD and MS conceptualised the study. DD and MS developed the study protocol. $\mathrm{RB}, \mathrm{KG}, \mathrm{AA}$, and DD performed patient screening and recruitment. NS performed biochemical and hormonal assays. UCG and MS performed the bone mineral and body composition assessment. MS and DD performed the statistical analysis. All authors contributed equally to the preparation of the manuscript.

\section{References}

1. Sharma N, Sharma LK, Dutta D, et al. Prevalence and Predictors of Thyroid Dysfunction in Patients with HIV Infection and Acquired Immunodeficiency Syndrome: An Indian Perspective. J Thyroid Res. 2015; 2015: 517173, doi: 10.1155/2015/517173, indexed in Pubmed: 26798547.

2. Dutta D, Dharmshaktu P, Aggarwal A, et al. Severity and pattern of bone mineral loss in endocrine causes of osteoporosis as compared to age-related bone mineral loss. J Postgrad Med. 2016; 62(3): 162-169, doi: 10.4103/0022-3859.183170, indexed in Pubmed: 27241810.

3. Biswas D, Dutta D, Maisnam I, et al. Occurrence of osteoporosis \& factors determining bone mineral loss in young adults with Graves' disease. Indian J Med Res. 2015; 141(3): 322-329, doi: 10.4103/0971-5916.156620, indexed in Pubmed: 25963493.

4. Brown TT, Qaqish RB. Antiretroviral therapy and the prevalence of osteopenia and osteoporosis: a meta-analytic review. AIDS. 2006; 20(17): 21652174, doi: 10.1097/QAD.0b013e32801022eb, indexed in Pubmed: 17086056.

5. Brown TT, McComsey GA. Osteopenia and osteoporosis in patients with HIV: a review of current concepts. Curr Infect Dis Rep. 2006; 8(2): 162-17 doi: 10.1007/s11908-006-0012-x, indexed in Pubmed: 16524553.

6. Welz T, Childs K, Ibrahim F, et al. Efavirenz is associated with severe vitamin D deficiency and increased alkaline phosphatase. AIDS. 2010; 24(12): 1923-1928, doi: 10.1097/QAD.0b013e32833c3281, indexed in Pubmed: 20588161.

7. Bonjoch A, Figueras M, Estany C, et al. Osteoporosis Study Group. High prevalence of and progression to low bone mineral density in HIV-infected patients: a longitudinal cohort study. AIDS. 2010; 24(18): 2827-2833, doi: 10.1097/QAD.0b013e328340a28d, indexed in Pubmed: 21045635

8. Maisnam I, Dutta D, Mukhopadhyay S, et al. Lean mass is the strongest predictor of bone mineral content in type-2 diabetes and normal individuals: an eastern India perspective. J Diabetes Metab Disord. 2014; 13(1): 9 doi: 10.1186/s40200-014-0090-5, indexed in Pubmed: 25229052.

9. McDermott AY, Terrin N, Wanke C, et al. CD4+ cell count, viral load, and highly active antiretroviral therapy use are independent predictors of body composition alterations in HIV-infected adults: a longitudinal study. Clin Infect Dis. 2005; 41(11): 1662-167 doi: 10.1086/498022, indexed in Pubmed: 16267741.

10. Leib E, Lewiecki E, Binkley $\mathrm{N}$, et al. International society for clinical densitometry. Official positions of the international society for clinical densitometry. J Clin Densitom. 2004; 7(1): 1-5, doi: 10.1385/jcd:7:1:1.

11. Klein S, Fabrini E, Romijn JA. Obesity. In: Melmed S, Polonsky KS, Larsen PR, Kronenberg HM. Williams textbook of endocrinology, Elsevier Saunders 12th edition. 2011; 36: 1605.

12. Liu LK, Lee WJ, Chen LY, et al. ILAS Research Group. Comparisons of sarcopenia defined by IWGS and EWGSOP criteria among older people: results from the I-Lan longitudinal aging study. J Am Med Dir Assoc. 2013; 14(7): 528.e1-528.e7, doi: 10.1016/j.jamda.2013.03.019, indexed in Pubmed: 23664768.

13. Cruz-Jentoft AJ, Baeyens JP, Bauer JM, et al. European Working Group on Sarcopenia in Older People. Sarcopenia: European consensus on definition and diagnosis: Report of the European Working Group on Sarcopenia in Older People. Age Ageing. 2010; 39(4): 412-423, doi: 10.1093/ageing/afq034, indexed in Pubmed: 20392703.
14. Reveille JD. The changing spectrum of rheumatic disease in human immunodeficiency virus infection. Semin Arthritis Rheum. 2000; 30(3): 147-166, doi: 10.1053/sarh.2000.16527, indexed in Pubmed: 11124280 .

15. Cuellar ML. HIV infection-associated inflammatory musculoskeletal disorders. Rheum Dis Clin North Am. 1998; 24(2): 403-421, doi: 10.1016/ s0889-857x(05)70015-6, indexed in Pubmed: 9606765.

16. Wren A. How best to approach endocrine evaluation in patients with HIV in the era of combined antiretroviral therapy? Clin Endocrinol (Oxf). 2013; 79(3): 310-313, doi: 10.1111/cen.12269, indexed in Pubmed: 23790012.

17. Brown TT. HIV: an underrecognized secondary cause of osteoporosis? J Bone Miner Res. 2013; 28(6): 1256-1258, doi: 10.1002/jbmr.1967, indexed in Pubmed: 23630095.

18. Fakruddin JM, Laurence J. HIV envelope gp120-mediated regulation of osteoclastogenesis via receptor activator of nuclear factor kappa B ligand (RANKL) secretion and its modulation by certain HIV protease inhibitors through interferon-gamma/RANKL cross-talk. J Biol Chem. 2003; 278(48): 48251-48258, doi: 10.1074/jbc.M304676200, indexed in Pubmed: 12975380

19. Dutta D, Maisnam I, Shrivastava A, et al. Serum vitamin-D predicts insulin resistance in individuals with prediabetes. Indian J Med Res. 2013; 138(6): 853-86 indexed in Pubmed: 24521626.

20. Sharma LK, Dutta D, Sharma N, et al. The increasing problem of subclinical and overt hypervitaminosis D in India: An institutional experience and review. Nutrition. 2017; 34: 76-81, doi: 10.1016/j.nut.2016.09.014, indexed in Pubmed: 28063517.

21. Dutta D, Mondal SA, Choudhuri S, et al. Vitamin-D supplementation in prediabetes reduced progression to type 2 diabetes and was associated with decreased insulin resistance and systemic inflammation: an open label randomized prospective study from Eastern India. Diabetes Res Clin Pract. 2014; 103(3): e18-e23, doi: 10.1016/j.diabres.2013.12.044, indexed in Pubmed: 24456991.

22. Chaudhary S, Dutta D, Kumar M, et al. Vitamin D supplementation reduces thyroid peroxidase antibody levels in patients with autoimmune thyroid disease: An open-labeled randomized controlled trial. Indian J Endocrinol Metab. 2016; 20(3): 391-398, doi: 10.4103/2230-8210.179997, indexed in Pubmed: 27186560.

23. Dravid A, Kulkarni M, Borkar A, et al. Prevalence of low bone mineral density among HIV patients on long-term suppressive antiretroviral therapy in resource limited setting of western India. J Int AIDS Soc. 2014; 17(4 Suppl 3): 19567, doi: 10.7448/ias.17.4.19567, indexed in Pubmed: 25394074

24. Zillikens MC, Uitterlinden AG, van Leeuwen JP, et al. The role of body mass index, insulin, and adiponectin in the relation between fat distribution and bone mineral density. Calcif Tissue Int. 2010; 86(2): 116-125, doi: 10.1007/s00223-009-9319-6, indexed in Pubmed: 19957167.

25. Kim CJ, Oh KW, Rhee EJ, et al. Relationship between body composition and bone mineral density (BMD) in perimenopausal Korean women. Clin Endocrinol (Oxf). 2009; 71(1): 18-26, doi: 10.1111/j.13652265.2008.03452.x, indexed in Pubmed: 19178508.

26. Lanyon LE, Rubin CT Static vs dynamic loads as an influence on bone remodelling. J Biomech. 1984; 17(12): 897-905, doi: 10.1016/00219290(84)90003-4, indexed in Pubmed: 6520138.

27. Brown TT, McComsey GA, King MS, et al. Loss of bone mineral density after antiretroviral therapy initiation, independent of antiretroviral regimen. J Acquir Immune Defic Syndr. 2009; 51(5): 554-561, doi: 10.1097/ QAI.0b013e3181adce44, indexed in Pubmed: 19512937.

28. Yin MT, Shi $\mathrm{O}$, Hoover DR, et al. Fracture incidence in HIV-infected women: results from the Women's Interagency HIV Study. AIDS. 2010; 24(17): 2679-2686, doi: 10.1097/QAD.0b013e32833f6294, indexed in Pubmed: 20859192.

29. Yin MT, Kendall MA, Wu X, et al. Fractures after antiretroviral initiation. AIDS. 2012; 26(17): 2175-2184, doi: 10.1097/QAD.0b013e328359a8ca, indexed in Pubmed: 22951635.

30. El-Maouche D, Xu X, Cofrancesco J, et al. Prevalence of low bone mineral density in a low-income inner-city population. J Bone Miner Res. 2011; 26(2): 388-396, doi: 10.1002/jbmr.221, indexed in Pubmed: 20721937.

31. Grant PM, Kitch D, McComsey GA, et al. Low baseline CD4+ count is associated with greater bone mineral density loss after antiretroviral therapy initiation. Clin Infect Dis. 2013; 57(10): 1483-1488, doi: 10.1093/ cid/cit538, indexed in Pubmed: 23943825.

32. Authier FJ, Chariot P, Gherardi RK. Skeletal muscle involvement in human immunodeficiency virus (HIV)-infected patients in the era of highly active antiretroviral therapy (HAART). Muscle Nerve. 2005; 32(3): 247-26 doi: 10.1002/mus.20338, indexed in Pubmed: 15902690.

33. Buehring B, Kirchner E, Sun Z, et al. The frequency of low muscle mass and its overlap with low bone mineral density and lipodystrophy in individuals with HIV--a pilot study using DXA total body composition analysis. J Clin Densitom. 2012; 15(2): 224-232, doi: 10.1016/j. jocd.2011.10.003, indexed in Pubmed: 22169198. 
34. Di Monaco M, Vallero F, Di Monaco R, et al. Prevalence of sarcopenia and its association with osteoporosis in 313 older women following a hip fracture. Arch Gerontol Geriatr. 2011; 52(1): 71-74, doi: 10.1016/j. archger.2010.02.002, indexed in Pubmed: 20207030.

35. Lang T, Cauley JA, Tylavsky F, et al. Health ABC Study. Computed tomographic measurements of thigh muscle cross-sectional area and attenuation coefficient predict hip fracture: the health, aging, and body composition study. J Bone Miner Res. 2010; 25(3): 513-519, doi: 10.1359/ jbmr.090807, indexed in Pubmed: 20422623.
36. Rozenberg S, Lanoy E, Bentata M, et al. ANRS 120 Fosivir Study Group. Effect of alendronate on HIV-associated osteoporosis: a randomized double-blind, placebo-controlled, 96-week trial (ANRS 120). AIDS Re Hum Retroviruses. 2012; 28(9): 972-98 doi: 10.1089/AID.2011.0224, indexed in Pubmed: 22353022

37. Bolland MJ, Grey A, Horne AM, et al. Effects of intravenous zoledronate on bone turnover and bone density persist for at least five years in HIV-infected men. J Clin Endocrinol Metab. 2012; 97(6): 1922-1928, doi: 10.1210/jc.2012-1424, indexed in Pubmed: 22419728. 